Danka Knezevic ${ }^{1}$, Maja Glogovac ${ }^{2}$, Nedeljko Zivkovic ${ }^{2}$, Milos Dukanac ${ }^{3}$

1 TD Consulting, Belgrade, Serbia

${ }^{2}$ University of Belgrade, Faculty of Organizational Sciences, Serbia

${ }^{3}$ MSC doo, Belgrade, Serbia

\title{
Assessment of the Stakeholders' Importance Using AHP Method - Modeling and Application
}

UDC: 005.311

DOI: 10.7595/management.fon.2015.0008

\begin{abstract}
Attention to stakeholders, which means that companies bear responsibility for the implications of their actions, is emerging as a critical strategic issue. Hence, meeting legitimate stakeholders' requests would enhance the reputation of a company and increase its competitiveness on product markets. That is why an accurate identification of stakeholders and assessment of their importance is so significant for the companies. Through an integration of the earlier models of excellence, models for identification and classification of stakeholders, models for assessing the quality of a company and the AHP method, widely applicable in various fields, a new model for assessment of stakeholders' significance is proposed in this paper. The model also provides an assessment of a company based on the degree of the importance and satisfaction of stakeholders. The results of this model could be useful for companies and their management when it comes to defining a proper business strategy, monitoring the system changes over time, creating a basis for comparison with other similar systems or with itself. A practical example is given to demonstrate the effectiveness of the model.
\end{abstract}

Keywords: stakeholders, assessment, AHP, model

\section{Introduction}

Drucker (1995) stated that every company is created to achieve some of the goals of individuals, groups, communities or social and state formations. Niven (2002) noted that the most common targets of companies are related to financial interests that indicate the growth, profitability and value of the organizational system. However, the interests should not be strictly financial, so Neely and Adams (2000) categorized them into the interests of individuals (owners, employees, management), the interests of organizations and the state's interests.

Vewing a company as a combination of explicit and implicit relationships (Aghion and Bolton, 1992; Baker et al., 2002), in terms of a broader view of resource-based theory that includes intellectual property (Takeya, 1997.), other parties in relationship with organization, not just the owners, should have the right to manage. Neglect of the rights of the other stakeholders does not do well in the real world (Stout, 2002). According to Schlierer (et al., 2012) companies have to take into account and integrate the needs of all their stakeholders in the way they operate their business to create and distribute value. As a result, stakeholder value is becoming increasingly embedded in the strategic thinking to generate a long-term economic value. Attention to stakeholders is emerging as a critical strategic issue (Crilly and Sloan, 2012) so dealing with this problem can be the basis for the sustainable management of organizational systems. Meeting legitimate stakeholders' requests would enhance a company's endowment of trust and reputation, which, in turn, would increase both access to resources on factors' markets and competitiveness on product markets (Minoja, 2012). Therefore, the management's $\square$ rst steps towards a corporate social responsibility policy consist of identifying the different stakeholders or their business and their representatives and analyzing their interests and expectations in relation to the business (Girard and Sobczak, 2012).

Over the last 30 years, much management research has consequently focused on the methods of analyzing and mapping stakeholders and their interests, as well as the way the business managers may handle their relationships with them (Stieb, 2009; Bevan and Werhane, 2011). While there is a well established body of literature that discusses stakeholder management, the concepts are not generally developed in ways that make them useful in practice (Ackermann, and Eden, 2011). 


\section{Literature review}

\subsection{Definitions of Stakeholders}

The notion of stakeholder was $\square$ rst adopted in organizational studies, primarily as a new way of understanding business organizations as opposed to the mainstream shareholder view of the company (Foo et al., 2011). Starting from Freeman's definition of stakeholders (1984), one can conclude that current or potential stakeholders may include any of the following categories: individuals, groups, organizations, institutions, generally, anyone in the region (Mitchell et al., 1997).

Thompson (et al., 1991) pointed out that stakeholders are the groups that are in some kind of relationship with the organization, while Clarkson (1994) described that relationship as a voluntary or involuntary exposure to risk. There is a number of other definitions in literature (Vos and Achlerkamp, 2004; Conti, 2004.; Boutelle, 2004.; Buysse and Verbeke, 2003.; Donaldson, 1999.; Clarkson, 1995; Donaldson and Preston, 1995), which generally can be subsumed under the definition that stakeholders are individuals, groups and organizations that affect and/or that are affected by the observed system.

\subsection{Evaluation of Stakeholders}

The impact of speci $\square$ c stakeholders is not always obvious (Coff, 1999). However, as the companies are limited in time and all other resources, it is impossible to meet the demands of all stakeholders so it is necessary to determine their priority at a certain moment.

In an attempt to further analyze the stakeholders on the project level, Boutelle (2004) pointed out four steps in stakeholders analysis. Mochal (2006) listed six steps. In both cases, the steps are almost identical, but none of them offers a concrete solution for the classification or determination of the stakeholder importance, considering that there is a difference between them.

The fact that stakeholders can be seen as active and passive (Vos et al., 2004), primary and secondary (Overseas Development Administration), internal and external or as voluntarily and involuntarily involved (Clarkson, 1994) confirms that there are differences among these parties from the standpoint of the importance to an organization.

Mitchell (et al., 1997) claims that all the stakeholders can be identified and classified on the basis of whether they have one, two or all three of the following attributes: power, legitimacy and urgency. Although this theory gives partial solutions to the problem "who or what is taken into account" (Freeman, 1994), when it is applied in practice, results are contrary to expectations. Firstly, it is not clear what criteria are used to determine whether the requests of observed stekeholder are legitimate or not. It is the same when it is comes to urgency, because it is clear that this criterion, like legitimacy, leaves much space for subjectivity. The power, defined as the ability of one party to influence the decisions of others (Dahl, 1957), is difficult to define but it is easy to recognize (Weber, 1947), which unfortunately cannot be applied to the previous two criteria. Moreover, it is not clear if an observed stakeholder should be given some of the attributes in case that different requests of the same stakeholder are evaluated differently according to some of the criteria. For example, the stakeholder has 6 requests, 3 of them are assessed as legitimate, while one of them is urgent and two of them are neither legitimate nor urgent. The question is whether the stakeholder should be given legitimacy and urgency.

The conclusion is that these criteria can be used for the evaluation of the stakeholders' significance only when they are observed on the level of their requests, under the condition that it is clearly defined from whose point of view the urgency and legitimacy will be assessed.

\section{Assessment of the stakeholders' importance using AHP method}

It is clear from the previous discussion that each organizational system has to meet the needs of stakeholders. As organizational resources and capabilities are limited, the ability to fulfill the needs of all stakeholders is also limited. However, not all the effects between the stakeholders and the company are of 
the same intesity, which indicates that their importance to the company is not the same. If a company knew the importance of each stakeholder, it would be able to focus resources on meeting those needs that would provide them long-term survival. Therefore, it is necessary to identify the stakeholders, determine their needs and determine their significance, and then implement that in the business strategy.

Integrating the previous models of excellence, models for identification and classification of stakeholders (Mitchell et al., 1997), models for quality assessment of the company and the AHP method, widely applicable in various fields (Chin et al., 2002; Kang and Lee, 2007; Tseng et al., 2007; Tseng et al., 2009.), a new model for assessment of stakeholders' importance is proposed in this paper. The model also provides an assessment of the company based on the degree of importance and satisfaction of stakeholders.

The results of this model could be useful for companies and their management to define a proper business strategy, monitor the system changes over time, create a basis for comparison with other similar systems or with itself ( $100 \%$ satisfaction - the best grade). Also, the model could be a good basis for the improvement of excellence model and similar systems of evaluation and comparison of organizational systems which are not strictly based on financial indicators.

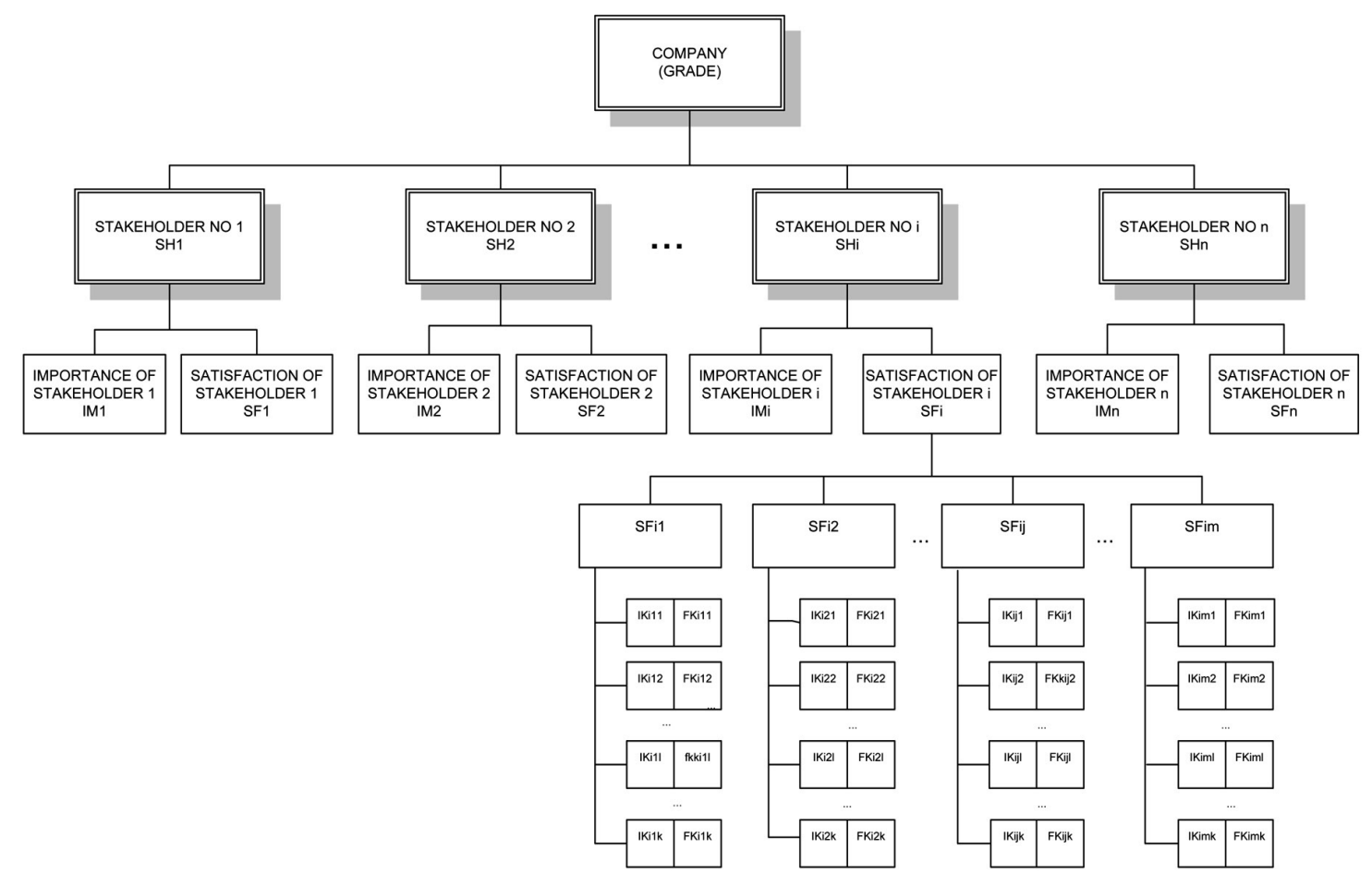

Figure 1. Model for assessment of stakeholders' importance

$$
\begin{aligned}
& E O C=I M_{1} \star S F_{1}+I M_{2} * S F_{2}+\ldots+I M_{i}^{*} S F_{i}+\ldots+I M_{n} * S F_{n}=\Sigma I M_{i} \star S F_{i}, i=1 \ldots n \quad(1) \\
& S F_{i}=\left(S F_{i 1}+S F_{i 2}+\ldots+S F_{i j}+S F_{i m}\right) / m=\Sigma S F_{i j} / m, j=1 \ldots m(2) \\
& \mathrm{SF}_{\mathrm{ij}}=\left(\mathrm{IK}_{\mathrm{ij} 1}{ }^{\star} \mathrm{FK}_{\mathrm{ij} 1}+\mathrm{IK}_{\mathrm{ij} 2}{ }^{\star} \mathrm{FK}_{\mathrm{ij} 2}+\ldots+\mathrm{IK}_{\mathrm{ijj}}{ }^{\star} \mathrm{FK}_{\mathrm{ijl}}+\ldots+\mathrm{IK}_{\mathrm{ijk}}{ }^{\star} \mathrm{FK}_{\mathrm{ijk}}\right) /\left(\mathrm{IK}_{\mathrm{ij} 1}+\mathrm{IK} \mathrm{K}_{\mathrm{ij} 2}+\ldots+\mathrm{IK}_{\mathrm{ijl}}+\ldots+\mathrm{IK} \mathrm{K}_{\mathrm{ijk}}\right)^{\star} \mathrm{FK}_{\mathrm{max}} \\
& =\Sigma I \mathrm{~K}_{\mathrm{ijj}}{ }^{\star} \mathrm{F} \mathrm{K}_{\mathrm{ij}} / \sum \mathrm{I} \mathrm{K}_{\mathrm{ij}}{ }^{\star} \mathrm{F} \mathrm{K}_{\max }, \mathrm{l}=1 \ldots \mathrm{k}, \mathrm{k}=\mathrm{f}(\mathrm{i})
\end{aligned}
$$

EOC - evaluation of the organizational system,

$\mathbf{I M}_{\mathbf{i}}$ - level of importance of stakeholder group $\mathrm{i}$, determined by using the AHP method,

$\mathbf{S F}_{\mathbf{i}}$ - level of satisfaction of stakeholder group $\mathrm{i}$,

$\mathrm{SF}_{\mathrm{ij}}$ - level of satisfaction of stakeholder $\mathrm{j}$, which belongs to the stakeholder group $\mathrm{i}$, 
$\mathbf{I K}_{\mathrm{ijl}}$ - level of importance of the request I, to the stakeholder $\mathrm{j}$, which belongs to the stakeholder group $\mathrm{i}$, $\mathrm{FK}_{\mathrm{ijl}}$ - level of importance of the request I according to oppinion of the stakeholder $\mathrm{j}$, which belongs to the stakeholder group i,

$\mathrm{FK}_{\max }$ - the highest possible mark for the requests, no metter if any stakeholder gave that mark to any request,

$\mathbf{n}$ - number of stakeholder groups,

$\mathbf{m}$ - number of stakeholders within one group, whose satisfaction is being evaluated (sample size),

$\mathbf{k}$ - overall number of requests according to which stakeholders are being evaluated. This number can vary depending on a stakeholder group.

The model aims to:

1. Take into account all the stakeholders,

2. Take into account the fact that the level of importance is a varying category,

3. Define elements for determing the level of importance of stakeholders,

4. Be flexible and general enough, in order to provide widespread use,

5. Be clear and easy to use,

6. Define the elements for further management and improvement of the organizational system.

The procedure consists of the following phases:

1. Stakeholder identification,

2. Evaluation of the importance of stakeholders,

3. Determination of the stakeholders' satisfaction,

4. Data processing and analysis.

Phase 1 involves identifying the broadest possible set of individuals, groups and organizations that can influence the company and/or are under the influence of the organizational system. In general, stakeholders can be classified into one of the following groups:

- The owners (shareholders, groups and individuals),

- Employees (management, executives),

- Suppliers,

- Customers and consumers,

- Banks (creditors),

- Donors,

- The state and its institutions at different levels (ministries, agencies, government, etc..)

- Competition,

- The community,

- Research institutions,

- Various activist groups and associations (consumer protection, business associations, trade unions, etc.).

On the basis of possible groups of stakeholders, identification of stakeholders for for each system will be done.

Phase 2 involves assessment, carried out by applying the AHP (Analytic Hierarchy Process) method and Expert Choice software. Decision-makers make the assessment of significance of each stakeholder and asign them some grade from Table 1. Data processing is done by using the software. The problem that will inevitably occur in this phase is the lack of clear criteria by which one can assign appropriate grade to one stakeholder compared with another stakeholder. The other problem is the subjectivity of decision makers. The former problem can be partially overcome by taking into account the long-term survival of the company as the basic criterion for the assessment of significance. Decision makers need to consider which of the two parties being compared is more important or whose (dis) satisfaction has a greater impact on a longterm survival of the organizational system. The latter is caused by the possibility that decision makers are the same ones who daily make decisions regarding the organizational system, ie., management. This is justified to some extent because management is responsible for leading and managing the organizational system, and therefore is responsible for its current state. Undoubtedly, someone who is responsible should be involved in decision making, but the question is how much one is able to perceive all aspects objectively. Therefore, it is proposed that representatives of all stakeholders should be involved into decision making. This would eliminate the subjectivity of some individuals to some extent and give a significantly more realistic evaluation of the importance of stakeholders. Also, it is suggested that the decision makers should, among 
others, be experts from the environment (some kind of consultants), as individuals who are familiar with this issue and who are unbiased because of their exclusion from a relationship with an organizational system.

Phase 3 involves an identification of the stakeholders' satisfaction through questionnaires. The questionnaire should be compiled with the representatives of stakeholders, because they are familliar with the widest range of requests of their stakeholder groups. For each of the identified groups of stakeholders a representative sample is defined and questionnaire is carried out. In the questionnaire, each stakeholder representative determines the significance of their requirements on the scale of 1 to 5 , and then evaluates compliance with the relevant requirements. In this way, obtaining a more realistic evaluation of satisfaction is provided, because it is clear that all entities, even within the same group of stakeholders (e.g. employees) do not have the same perception of the significance of individual requirements.

Table 1: Assessment phase and determination of the stakeholders' satisfaction

\begin{tabular}{|c|l|}
\hline GRADE & \multicolumn{1}{c|}{ EXPLANATION } \\
\hline 9 & Absolutely the most significant stakeholder \\
\hline 8 & The most significant stakeholder \\
\hline 7 & Exceptionally significant stakeholder \\
\hline 6 & Pretty significant stakeholder \\
\hline 5 & Significant stakeholder \\
\hline 4 & Very important stakeholder \\
\hline 3 & Important stakeholder \\
\hline 2 & A little important stakeholder \\
\hline 1 & Equally important stakeholder \\
\hline
\end{tabular}

The example of the questionnaire

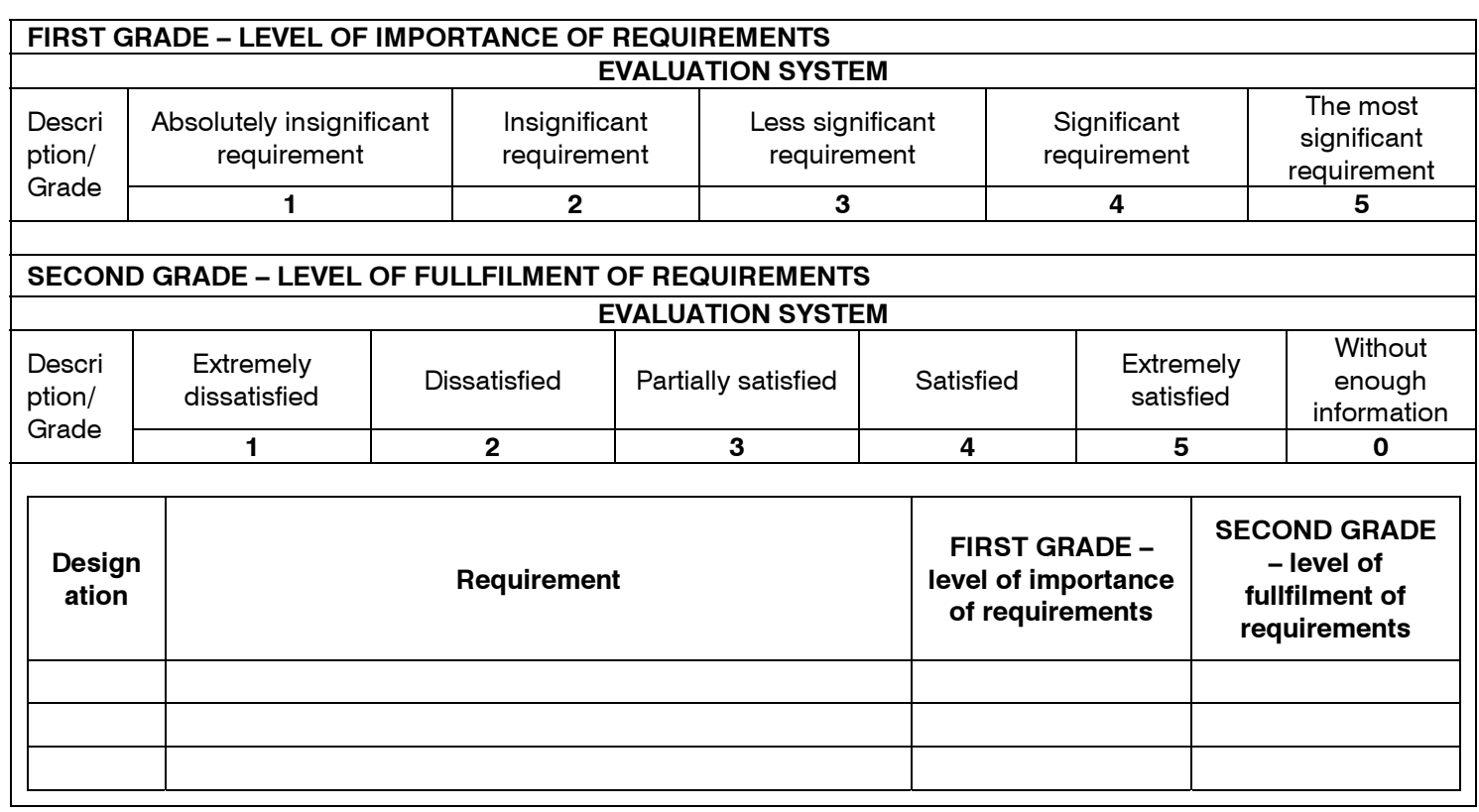

Before this phase is carried out completely, a pilot questionnaire should be conducted after identifying the requirements. It should include open questions, ie., space for additional requirements that may not be covered by the questionnaire, in order to avoid the risk of omitting important requirements. If respondents point out additional requirements in the pilot questionnaire, the questionnaire should be complemented by adding the missing requirements or by a different formulation of the existing one. The questionnaire should be changed if there are significant number of grades "0" (not enough information to assess the fulfillment of the requirements), because it indicates a potential lack of understanding of the requirements or even lack of significance of the requirements for the relevant stakeholders. 
The problem that could occur in this phase is the inability to interview some stakeholders which should be taken into account as a limiting factor. The proposal is to conduct phase 2 again in the way that stakeholders whose significance cannot be determined should be omitted from the assessment of the significance. Such an act will give an incomplete picture of the observed system, but it will eliminate errors that would occur if the significance of those stakeholders was evaluated (because of the application of the AHP method, the sum of importance of all stakeholders must be 1)

Phase 4 involves data processing according to the previously expleined mathematical model.

\section{The practical example}

The model was applied in the company that has existed for more than 70 years manufacturing footwear (safety, recreational and shoes of general purpose). It operates as a limited company, with less than 1000 employees.

It was noticed in the first phase that the company had no donors, so this group of stakeholders was omitted. It was also noticed that the system has not had any contact with scientific institutions so this group of stakeholders was also omitted, while the social community, because of limited factors, was seen only through the non-governmental organizations and association, without directly interviewing citizens. In the evaluation of the significance of stakeholders representatives of all stakeholders were included, provided that the management of the company had the largest number of representatives. The total number of decision makers was 15, one representative for each group, provided that the owners had 2 representatives, the management had 5 representatives, and one expert, who was not in any relation with the company, was hired.

The questionnaire for each group of stakeholders was compiled together with the management and representatives of the other groups of stakeholders and it was tested on test sample. The test sample pointed out the need for complementing requirements of two groups and reformulating requirements of four groups of stakeholders.

Depending on the (estimated) number of stakeholders within the observed group, a representative sample was selected and the results are shown in Table 2. Interviewing lasted for four months, and questionaires were delivered in a way that was the most convinient for the respondents (e-mail, fax...), ensuring anonymity as much as possible. After four months, the response rate exceeded $90 \%$, so an overview of the situation was made and the results are shown below.

Table 2: Representative sample

\begin{tabular}{|c|c|c|c|}
\hline No & Stakeholder & Sample size & Note \\
\hline 1. & Banks & $100 \%$ & \\
\hline 2. & Customers & $10 \%$ & $\begin{array}{l}\text { Domestic and foreign customers were taken into } \\
\text { account. Customers with significant annual volume of } \\
\text { buying were selected. }\end{array}$ \\
\hline 3. & The state & $100 \%$ & $\begin{array}{l}\text { Representatives of all state institutions in the } \\
\text { community and the region who are significant for } \\
\text { research were selected. }\end{array}$ \\
\hline 4. & Suppliers & $10 \%$ & $\begin{array}{l}\text { Domestic and foreign suppliers were taken into } \\
\text { account. Suppliers with significant annual volume of } \\
\text { trade were selected. }\end{array}$ \\
\hline 5. & Competitors & $100 \%$ & \\
\hline 6. & $\begin{array}{l}\text { Non-governmental } \\
\text { organizations, } \\
\text { Associations } \\
\text { (Social community) }\end{array}$ & $100 \%$ & $\begin{array}{l}\text { Representatives of non-governmental organizations, } \\
\text { sports associations etc. in the community were } \\
\text { selected. }\end{array}$ \\
\hline 7. & Employees & $10 \%$ & $\begin{array}{l}\text { Employees within different organizational sectors, of } \\
\text { different gender and age were taken into account. }\end{array}$ \\
\hline 8. & Owners & $100 \%$ & $\begin{array}{l}\text { All the members of board of directors were taken into } \\
\text { account as representatives of other stockholders. }\end{array}$ \\
\hline 9. & Management & $100 \%$ & \\
\hline
\end{tabular}


After the survey was conducted, the results are analyzed and presented in Table 3, as well as the results of evaluation of significance of stakeholders.

Table 3: Results

\begin{tabular}{|c|c|c|c|c|}
\hline No & Stakeholder & $\begin{array}{c}\text { Level of satisfaction } \\
\qquad \mathrm{SF}_{\mathrm{i}}\end{array}$ & $\begin{array}{l}\text { Level of importance } \\
\qquad \mathrm{IM}_{\mathrm{i}}\end{array}$ & Final grade \\
\hline 1. & Employees & 59.840 & 0.162 & 9.694 \\
\hline 2. & Management & 65.600 & 0.184 & 12.070 \\
\hline 3. & Owners & 70.000 & 0.206 & 14.420 \\
\hline 4. & Banks & 76.670 & 0.062 & 4.753 \\
\hline 5. & Customers & 78.880 & 0.209 & 16.486 \\
\hline 6. & Competitors & 80.000 & 0.037 & 2.960 \\
\hline 7. & Suppliers & 82.600 & 0.049 & 4.047 \\
\hline 8. & $\begin{array}{l}\text { Non-governmental } \\
\text { organizations, } \\
\text { Associations }\end{array}$ & 92.670 & 0.021 & 1.946 \\
\hline 9. & The state & 93.930 & 0.070 & 6.575 \\
\hline \multicolumn{4}{|c|}{ The grade of the organizational system } & 72.951 \\
\hline
\end{tabular}

The results show that of greatest importance to the company are customers, and then owners, management and employees. This assessment of significance probably has its roots in the quality management system that is implemented and certified. The owners, management and employees are the internal stakeholders that are directly related to the top management, and are also part of the organizational system, so paying attention to them is logical.

Figure 2: Evaluation of importance of the stakeholders $\left(\mathrm{IM}_{\mathrm{i}}\right)$

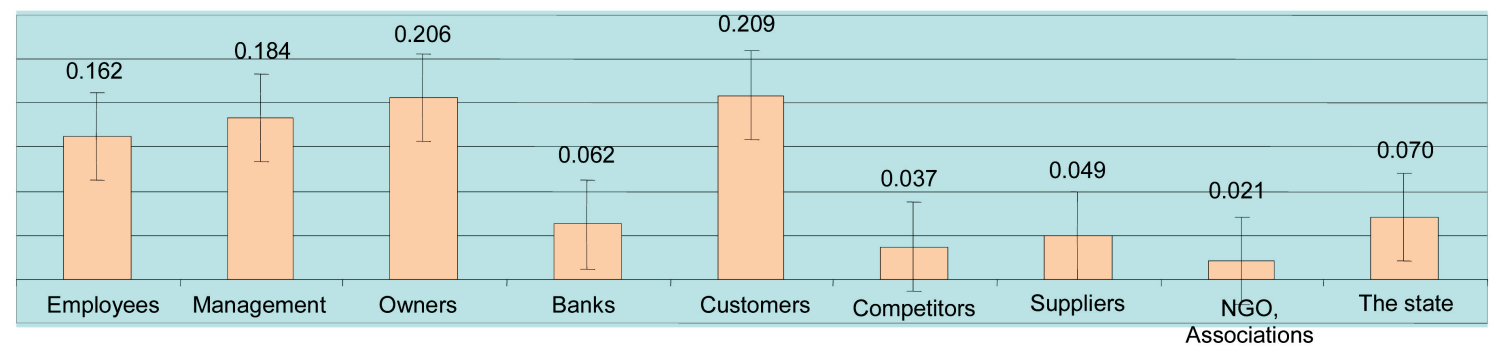

The questionaires, which were to determine the level of satisfaction of identified stakeholders, showed that stakeholders that were evaluated as the most important expressed the lowest level of satisfaction. Employees, management and owners are the least satisfied with the fulfillment of their requirements, while customers' level of satisfaction is in the middle. The state, non-governmental organizations and other associations as representatives of the community expressed a very high level of satisfaction, although they have the lowest significance for the organizational system.

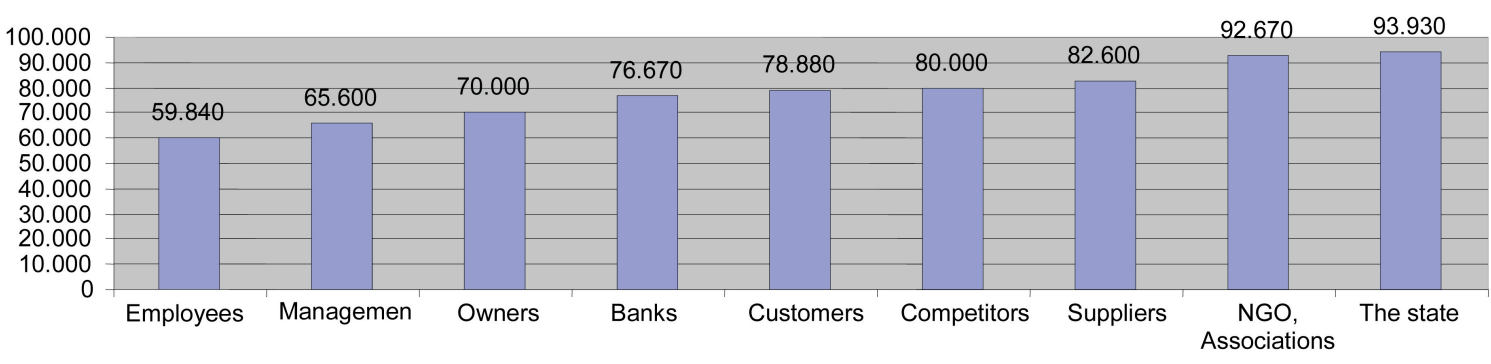

Figure 3: Evaluation of satisfaction of the stakeholders $\left(\mathrm{SF}_{\mathrm{i}}\right)$ 
Observing the participation in the final grade of organizational system, it is clear that customers, owners, management and employees have a key share. The final grade of the company was 72,951 compared to a maximum of 100 .

However, at this level of information availability, it is difficult to make any judgment on whether this grade is acceptable or not, since there are no data on the evaluation in a prior period or some other system with which this grade could be compared. What is certain is that the company should take appropriate measures to increase the satisfaction of the most important groups of stakeholders, especially employees, since they are the least interested party.

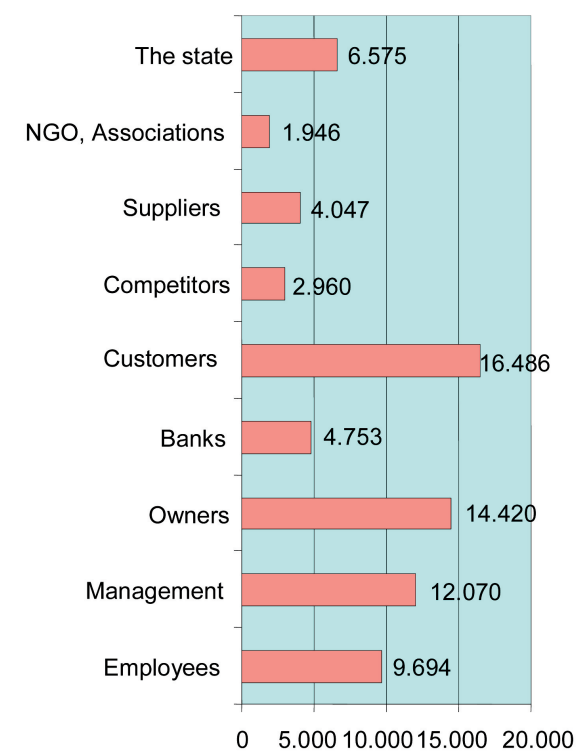

Figure 4: The share of stakeholders in the final grade of the organizational system

Conclusion

The stakeholder theory advocates that companies bear responsibility for the implications of their actions (Fassin, 2012). The stakeholder theory addresses morals, values, and ethical obligations explicitly as a central feature of organizational management (Phillips et al., 2003). Dealing with this, organizations could achieve success so it is important thet shareholders should be defined well and then evaluated.

The idea is that the requirements of stakeholders and the level of their satisfaction should be the basic concern in decision-making and evaluation of an organizational system. The possibility to evaluate the company according to the level of fulfillment of its stakeholders' requirements is confirmed by the models of excellence, i.e., the Deming application prize award and Malcolm Baldrige quality award. Those models clearly indicate the importance of stakeholders' involvement, but in addition to the noticed shortcomings (Eskildsen et al., 2002.) they do not consider who stakeholders are, how they and their requirements can be identified, categorized and, finally, how final grade of observed organizational system is to be determined. Therefore, in this paper, we propose a model for evaluating the stakeholders, based on the AHP method.

The model is applicable in practice, as shown in the practical example and it can be considered as a partial improvement in comparison with the previous models. However there are still a lot of unresolved issues. Subjectivity in assessing the significance of the stakeholders is one of them. All the decision makers should consider in detail the criteria according to which significance will be evaluated. 
Also, the model does not provide a clear guidance on when and how often to evaluate the significance of stakeholders, considering that it is a variable category. Furthermore, some groups of stakeholders should be separated in order to get the most realistic picture. This primarily refers to the customers who undoubtedly have different views and interests in dealing with a company. The question that the model also failed to answer is related to the level of thoroughness of the identification of stakeholders. Where is the limit to which one should go in order to identify those who have an impact on the company or who are affected by it? Should the analysis be reduced only to direct impact, or those who are indirectly exposed to the effect should also be considered (e.g. owners of local stores whose business directly depends on the purchasing power of the people who are employed in the observed organizational system)?

A further direction of the model development should be the identification of relationships between the characteristics (performances) of a company and the stakeholders' requirements. Performances can be seen in several hierarchical levels, from the simplest to the most complex. Under the complexity we consider the comprehensiveness that is interdependent with the performance of the performances of the lower hierarchy level, as shown in the figure 5. (eg. profit directly depends on income and expenses, so it is at the higher level of hierarchy). Furthermore, it would be necessary to find a direct link between each requirement with at least one performance, and vice versa, given that one performance can be linked with many requirements.

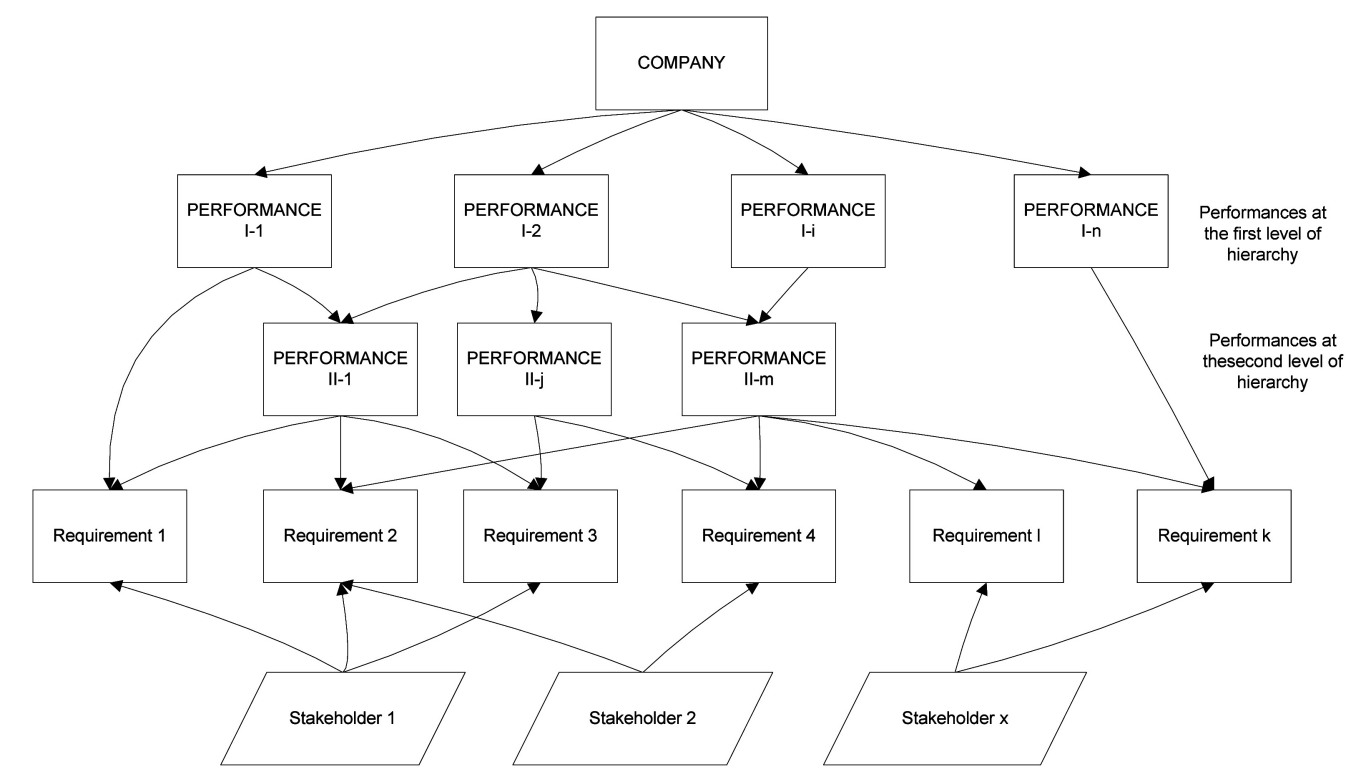

Figure 5: Link among performances of a company and stakeholders' requirements

In that case, decision-makers would have a more complex task, because they should determine the importance of each stakeholder in relation to all performances at the highest hierarchical level, so the model could look like as shown in the Figure 6. Evaluation of significance would be done by using the AHP method, with the difference that the final grade of one stakeholder would be calculated on the basis of more individual grades of significance where the number of those grades would be equal to the number of performances at the highest hierarchical level. The rest of the procedure would remain the same. 


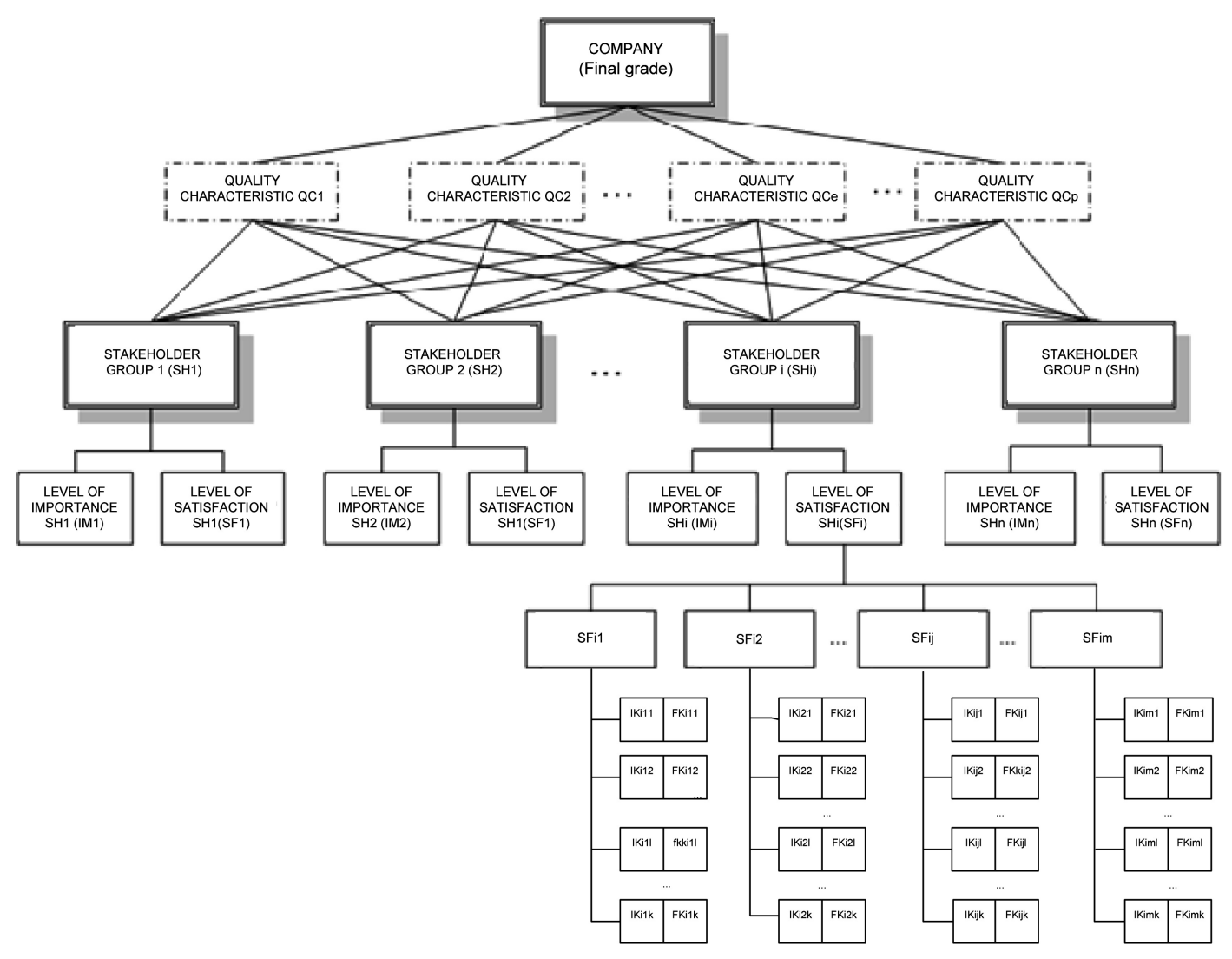

Figure 6: The extended model for evaluation of significance of stakeholders

\section{REFERENCES}

[1] Ackermann, F., \& Eden, C. (2011). Strategic management of stakeholders: theory and practice. Long Range Planning, 44(3), 179-196.

[2] Aghion, P., \& Bolton, P. (1992). An 'incomplete contracts' approach to financial contracting. Review of Economic Studies, 59(3), 473-494.

[3] Baker, G., Gibbons R., \& Murphy, K. J. (2002). Relational contracts and the theory of the firm. Quarterly Journal of Economics, 117(1), 39-83.

[4] Bevan, D., \& Werhane, P. H. (2011). Stakeholder theory. In M. Painter-Morland \& R. Ten Bos (Eds.), Business ethics and continental hilosophy. Cambridge: Cambridge University Press.

[5] Boutelle, J. (2004.). Understanding Organizational Stakeholders for Design Success, http://www.boxesandarrows.com/view/understanding_organizational_stakeholders_for_design_success

[6] Buysse, K., \& Verbeke, A. (2003). Proactive environmental strategies: $\bar{A}$ stakeholder management perspective. Strategic Management Journal, 24(5), 453-470.

[7] Chin, K.-S., Pun, K.-F., Xu, Y., \& Chan, J.S.F. (2002). An AHP based study of critical factors for TQM implementation in Shanghai manufacturing industries. Technovation, 22(11), 707-715.

[8] Clarkson M. (1994). A risk based model of stakeholder theory. Proceedings of the Second Toronto Coference on Stakeholder Theory, Toronto: Center for Corporate Social \& Ethics, University of Toronto.

[9] Clarkson, M. (1995). A stakeholder framework for analyzing and evaluating corporate social performance. Academy of Management Review, 20(1), 92-117.

[10] Coff, R. (1999). When competitive advantage doesn't lead to performance: the resource-based view and stakeholder bargaining ower. Organization Science, 10(2),119-133.

[11] Crilly, D., \& Sloan, P. (2012). Enterprise logic: explaining corporate attention to stakeholders from the 'inside-out'. Strategic Management Journal, 33(11), 1174-1193. 
[12] Dahl, R.A. (1957). The concept of power. Behavioral Science, 2(3), 201-215.

[13] Donaldson T., \& Preston, L. E. (1995). The stakeholder theory of the corporation: concepts, evidence and implications. Academy of Management Review, 20(1), 85-91.

[14] Donaldson, T. (1999). Making stakeholder theory whole. Academy of Management Review, 23(2), 237241.

[15] Drucker, P. F. Post-capitalist association, Poslovni sistem Grmeč-Privredni pregled, Belgrade, 1995.

[16] Eskildsen J., Kristensen, K., \& Juhl, J. (2002). Trends in EFQM Criteria Weights - The case in Denmark 1998-2001, Measuring Business Excellence, pp. 22-28.

[17] Fassin, Y. (2012). Stakeholder Management, Reciprocity and Stakeholder Responsibility. Journal of Business Ethics, 109(1), 83-96.

[18] Foo, L.M., Asenova, D., Bailey, S., \& Hood, J. (2011). Stakeholder Engagement and Compliance Culture. Public Management Review, 13(5), 707-729.

[19] Freeman, R.E. (1984). Strategic management: A stakeholder approach. Boston, Pitman.

[20] Freeman, R.E. (1994). The politics of stakeholder theory: Some future directions. Business Ethics Quarterly, 4(4), 409-421.

[21] Girard, C., \& Sobczak, A. (2012). Towards a Model of Corporate and Social Stakeholder Engagement: Analyzing the Relations Between a French Mutual Bank and Its Members, Journal of Business Ethics, $107(2), 215-225$.

[22] Kang, H-Y. \& Lee, A.H.I. (2007). Priority mix planning for semiconductor fabrication by fuzzy AHP ranking. Expert Systems with Applications, 32 (2), 560-570.

[23] Minoja, M. (2012), Stakeholder Management Theory, Firm Strategy, and Ambidexterity. Journal of Business Ethics , 109(1), 67-82.

[24] Mitchell, R., Agle, B., \& Wood, D. (1997). Toward A Theory of Stakeholder Identification And Salience: Defining The Principle of Who And What Really Counts. Academy of management review, 22(4), 853886.

[25] Mochal, T. (2006). Use stakeholder analysis to meet the needs of all interested parties. http://articles.techrepublic.com.com/5100-10878_11-6077367.html.

[26] Neely, A., \& Adams, C. (2000). Perspectives on performance: the performance prism, Handbook of Performance Measurement, Gee Publishing, London.

[27] Niven, P.R. (2002). Balanced Scorecard Step-by-Step. John Wiley and Sons, Inc, New York.

[28] Phillips, R., Freeman, R. E., \& Wicks, A. C. (2003). What Stakeholder Theory Is Not. Business Ethics Quarterly, 13(4), 479-502.

[29] Schlierer, H.J., Werner, A., Signori, S., Garriga, E., von Weltzien Hoivik, H., Van Rossem, A., \& Fassin, Y. (2012). How do European SME owner-managers make sense of 'Stakeholder Management'? Insights from a cross-national study. Journal of Business Ethics, 109(1), 39-51.

[30] Stieb, J. A. (2009). Assessing Freeman's stakeholder theory. Journal of Business Ethics, 87(3), 401-414.

[31] Stout, L. A. (2002). Bad and not-so-bad arguments for shareholder primacy. Southern California Law Review, 75(5), 1189-1209.

[32] Takeyama, L. N. (1997). The intertemporal consequences of unauthorized reproduction of intellectua property. Journal of Law and Economics, 40(2),511-522.

[33] Thompson, J.K., Wartick S.L., \& Smith, H.L. (1991). Integrating corporate social performance and stakeholder management: Imlications for a research agenda in small business. Research in Corporate Social Performance and Policy, 12(2), 207-230.

[34] Tito, C. (2004). Making Stakeholdsrs A Strategic Asset. American Society for Quality Control, Inc. 0033$524 X$.

[35] Tseng, M.L., Lin, Y.H., Chiu, A.S.F., \& Liao, C.H. (2007). A structural equation model of total quality management and cleaner production implementation. The Journal of American Academy of Business, 11(1), 65-71.

[36] Tseng, M-L., Lin, Y-H., \& Chiu, A.S.F. (2009). Fuzzy AHP-based study of cleaner production implementation in Taiwan PWB manufacturer. Journal of Cleaner Production, 17(4), 1249-1256.

[37] Vos, J.F.J., \& Achlerkamp, M.C. (2004). An instrumentfor stakeholder identification: Phasing roles of involvement. University of Groningen, Research Institute SOM (Systems, Organisations and Management), Research Report, 04B32.

[38] Weber, M. (1947). The theory of social and economic organization. New York, Free Press. 


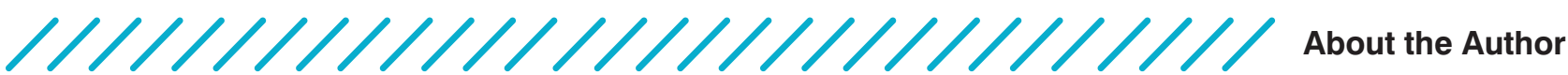

\section{Danka Knezević \\ TD Consulting, Belgrade, Serbia}

Danka Knezević, MSc., is PhD candidate at the Faculty of Organizational Sciences, University of Belgrade, Serbia. She has been concerned with improving the process and the implementation of international standards for more than eight years. Up to now, she has completed over 130 projects and has published over 20 papers in this field. Currently, she works as a director at the consulting firm TD Consulting.

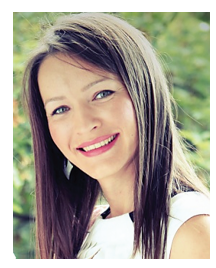

Maja Glogovac University of Belgrade, Faculty of Organizational Sciences, Serbia glogovac.maja@fon.bg.ac.rs

Maja Krsmanović, MSc., works as a teaching assistant at the Faculty of Organizational Sciences, University of Belgrade, Serbia, where she obtained her BSc and MSc degrees. Currently, she is a PhD student. Her major interests are quality management, process control and standardization. She has published over 30 papers in this field.

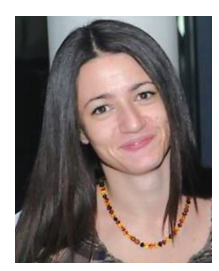

\section{Nedeljko Zivković \\ University of Belgrade, Faculty of Organizational Sciences, Serbia zivkovic.nedeljko@fon.bg.ac.rs}

Assistant Professor Nedeljko Zivković, Ph.D., is a Quality management assistant professor at Belgrade University, Faculty of Organizational Sciences (Serbia). He earned his Ph.D. from Belgrade University (Serbia) Faculty of Organizational Sciences and his BSME from Belgrade University, School of Mechanical Engineering. He is a registered quality management system lead auditor. Among many, his consulting activities include those in implementing management systems. He is the author of a large number of papers published in international and Serbian journals.

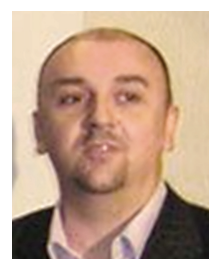

Milos Dukanac MSC doo, Belgrade, Serbia

Milos Dukanac, MSc., graduated from the Faculty of Organizational Sciences Department of Quality Management, University of Belgrade. He obtained his Master deegre in Quality engineering in 2012 at the Faculty of organizational sciences. In 2012 he started to work for the "Management Systems Certification" d.o.o., an accredited certification body for management systems certification, as a Certification manager, with the following main responsibilities: creating business policies and procedures, promotion, communication to clients and other stakeholders, resolving complaints, evaluation of customer satisfaction, development of new services in the area of management systems, conducting trainings on international standards application.

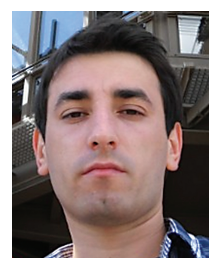

